\title{
Archetype and matrix image (potential forms of an image)
}

\section{Błocian}

University of Wrocław,

1, plac Uniwersytecki, Wrocław, 50-137, Poland

For citation: Błocian I. Archetype and matrix image (potential forms of an image). Vestnik of Saint Petersburg University. Philosophy and Conflict Studies, 2021, vol. 37, issue 1, pp. 154-161. https://doi.org/10.21638/spbu17.2021.112

The article is devoted to the analysis of potential forms of the image in culture and the development of the Jungian concept of an archetype in Wunenburger, Bachelard, Durand and modern cultural studies. The notion of archetype in Carl Jung's concept is related to the distinction between the archetype in itself, noumenon and archetype image conceived as a phenomenal manifestation of archetypal forms in the space-time, historical and social reality. This distinction has a Kantian lineage, which Jung was clearly conscious of. He provides a reference to the conception of Kant, calling it "a school of philosophical criticism" several times in his writings. In the studies of Jung's concept, his approach to transcendentalism (Z. Rosińska) is at times present, and a certain type of its specific, evolutionary interpretation is used. The archetype, being a "thing in itself", determines the appearance of phenomenal forms in the space-time, historical and social world, while remaining outside the direct entanglement and referring to the evolutionally active sphere of the unconscious as an anthropological datum. The archetypal image expresses the permanent approximation of manifestation of the semantic core of the archetype itself. The notion of an archetype has evolved in contemporary understandings and conceptions; it was conceived as a psychological expression of the evolutionary pattern of behavior, as an affectiverepresentative node and ante rem of an idea, as a hermeneutic pattern of meaning or as a kind of matrix image. The archetype can be understood in connection with anthropological structures or with a cultural image; one way of comprehension does not exclude the other.

Keywords: archetype, matrix image, primordial image, anthropological structures, epithetic archetypes, substantial archetypes, Jung, Bachelard, Durand, Wunenburger.

The concept of an archetype is related to another notion, a "matrix image". The first concept has a long, historical and philosophical heritage, and it was used and propagated in $20^{\text {th }}$ century thought especially by Carl Jung. The latter is associated with contemporary typologies of images in Jean-Jacques Wunenburger's understanding. There is a connection between one and the other because one of the types of matrix images, according to this division, is the archetype, but there are many more, among others: scheme, prototype or paradigm. In such a relation of concepts, the archetype seems to be a notion less general than the matrix image, but it is much more complex and can be understood in many other ways. Matrix images would therefore belong to "a certain category of mental images that have not yet been developed, have not reached the stage of a clear, finite representation neither in the mental sphere, nor in the material form" [1, p.40]. As a result, these are certain "seed forms" of image formation where there are primary general ways of shaping mental images in nuce, in which visual information is potential, parent, "embryonic" [1, p.41]. Their names and ways of understanding refer sometimes to specific hierarchies of generality with reference to metaphysical solutions.

(c) St. Petersburg State University, 2021 
The notion of archetype in Jung's conception is associated to some extent with this approach to the matrix image. The archetype itself is just such a potential form of grip, but Jung referred to matrix images in accordance with its forms of manifestation in the space-time world, in the form of archetypal images. The meanings in both shots are therefore shifted.

\section{Jung - evolution of the archetype notion}

Jung used the concept of an "archetype" (Archetypus) only from around 1919. Earlier texts had other similar meanings, such as imago, imagines or dominant. Following this, there were many different meanings and terms used. Many of them enter into certain interpretative dilemmas, if not contradictory relationships [2;3]. They were built in the space of the development of his conception and one can distinguish at least several stages that make up the evolution of his shots. Roger Brooke suggests, noting the most general direction of the concept and its development from evolutionary-biological, archetypes as psychic forms of a biological manifestation pattern of behavior to some kind of hermeneutics - archetypes as a hermeneutic pattern of meaning [4]. The evolutionary significance of an archetype never was rejected by Jung; however, he also knew the philosophical origin of the concept, and this is significant in understanding his conception [5].

Jung referred to certain stages of the evolution of the meaning of the concept in the history of ideas. His references to philosophical sources point toward St. Augustin's ideae principales, "Archetypal Forms" of Corpus Hermeticum and philosophy of St. Irenaeus from Lyon. It is clear that the concept is still active in Renaissance philosophy (Pico della Mirandola and archetypes according to which God creates certain entities and species), modern German philosophy [6], Kant and Scheler's grasp of some level of mind as intellectus archetypus or in contemporary reflection of religious imagination as seen with Henry Corbin's mundus archetypus [7]. Another, not directly related to the name, historical and philosophical way of influencing the formation of his understanding of the concept is to relate it to Kant's notion and his differentiation between thing in se (noumenon) and phenomenon. In Jung's perspective, archetype per se, in se is an unattainable core of archetype and archetypal image (historical and social manifestations of an archetypal core, phenomenon [8-10]). This influence is manifested in Jung's consistent maintenance of the distinction and his opposition to interpret his understanding of the "innate images" of the mind, which does not mean, however, that he did not recognize archetypal forms as innate. Thus, the evolutionary heritage of the species is always present, but they do not take the form of ready-made images, except under the influence of a particular historical, social and cultural reality. Thus they are just the ability to perform, capture and imaging. It is a kind of specific combination of two perspectives which are not usually combined - evolutionary and transcendental. There is a strong evolutionary-anthropological component, and on the other hand, the historical-philosophical component in the form of a specific interpretation of the conception of Kant and the approach to the philosophy of Schopenhauer (unconscious will as the noumena sphere) and von Hartmann.

\section{Matrix images. Jean Jacques Wunenburger}

Images are visual information carriers; matrix ones contain it in the germ or in embryonic forms. These are images that "contain native (matrix. - I. B.) information on derivative images" [1, p. 41]. There are many kinds of such "maturing" images: 1) diagrams 
(germs of future images);2) archetypes (master images of the entire series, invariable matrix of images); 3) type (imprint of the whole series); 4) prototype (primary image, model); 5) paradigm (simplified image to carry); 6) ideal type (summarizes in one form common features). The schemas can be included (after Durand and Wunenburger) as "verbalmotor cores of human expression" [1, p.41]. The Kantian scheme is the preparation of forms of understanding to accept specific empirical content. The diagram itself can show the relationship between general levels of orderliness and detailed ones. It is particularly valuable for science and is often used in it. Images in scientific practices can be understood as effective in explanatory and experimental terms [1, p. 184-185]. Imagination in science, in some refined and simplified form, submits to logical thinking structures and empirical data; it can be seen as an "ally of science" at various stages of scientific cognition, gathering visual information, creating models, interpretations, and an explanatory scheme. The image itself is, after all, an "observation instrument". Visual schematization reveals the structures of processes and objects themselves. Sometimes it is understood as a kind of "simplified eidetic view" [1, p. 189] that appears after filtering and reorganizing information. On the one hand, one can point to its poor and simplified forms, and on the other, the importance of the structure. There is, therefore, a certain correlation, above all in Wunenburger's approach, with the archetype (as Urbild) seen as some potential condensation, an "unchanging matrix of potential images" [1, p. 41]. It is interpreted anthropologically as instinctive mnemic settlements. For Durand, however, it is secondary to the pattern, because it already details the simplest schematic structures. Other types of matrix images assume the existence of certain traces of the production (types) of a multitude of images according to a specific semantic similarity and indicate their original location (prototype) or ability to replicate themselves (stereotype). Particularly important from the scientific point of view are paradigms creating very simplified and general forms of ordering, which cover a wide spectrum of research on processes and objects as well as ideal types condensing their semantic similarities. Imagination and matrix images understood in this way have a large impact on many procedures: visual representation systems, visual recognition and the retrieval of information, the role of photography and photographic documentation, the creation of electronic images that allow for viewing and simulation, interpretation and dissemination of knowledge. Imagination is not a field that frees from everyday life and breaks the "iron logic" [11, p. 12], although it may fulfill such functions. It is necessary in science that is not "rooted in the world of mathematical formulas and concepts" [1, p. 191].

\section{Durand - archetype and image}

Gilbert Durand ${ }^{1}$ was inspired by the Bachelardian philosophy of imagination [12], although he sometimes presented it critically leaving a certain split between the image and the concept [13]. Durand used the results of research on Bachelard's imagination, as well as the archetype and archetypal images in the Jung conception.

${ }^{1}$ A part concerning G. Durand's conception is developed from a fragment of my text: Błocian, I. (2017), Obrazy matrycowe, obrazy mityczne w filozoficzno-antropologicznym ujęciu C. G. Junga, G. Bachelada, G. Duranda i J.-J. Wunenburgera [Matrix Images, Mythical Images in Philosophlico-Anthropological Grasps of C. G. Jung, G. Bachelard, G. Durand and J.-J. Wunenburger], in Kampka, A., Kyrijów, A. and Sobczak, K. (eds), Czy obrazy rządza ludźmi? [Do Images Rule the People?], Warszawa: Wydawnictwo SGGW. 
References to their work are very frequent, and sometimes also critical, but Durand accepts several of Bachelard's assumptions: "Finally, Bachelard founded his general conception of symbolism on two assumptions that we would make our own: imagination is organizing dynamism, and this organizing dynamism is a factor of homogeneity in representation" [13, p. 26].

For Durand, symbolic imagination and image thinking serve as the basis for the functioning of the mind and psyche. They express and operate on anthropological structures, mediating between the activity of the senses and the formation of concepts, but they also create some of their own autonomous activity. Their basic role was to adapt to the living environment, but due to the possibility of its transformation they played and also play the role of "suspending" the meaning of stimuli and data flowing from the environment, i.e., the role of "re-realization". Imagination is such an organizing dynamic activity concerning even time: "imagination organizes and measures time, arranges time through historical myths and legends..." [13, p. 224].

Durand points to the combination of neurobiological, anthropological and cultural levels in the process of image formation. Thinking by image is the basis for thinking in general [14]. Imagination is a process that organizes and embeds its organization principles into the image itself [14, p.26]. Symbolic imagination is therefore studied in the closest relationship between the three forms of its disclosure of the image, archetype and myth. It is in them that it manifests itself in the life of culture, arising at neurobiological, anthropological and species levels within anthropological structures. These structures govern human orientation and adherence to the environment (e.g., evolution privileges two paths of sensual relationship with the world: visual and audiophonic [14, p. 176]; "corps entier collabore à la constitution de l'image" ("the whole body cooperates to build an image") [14, p. 50], and creative transformation of this environment along with all the shortcomings of this process. However, it is not only originally mediating and organizing, but rather creative, partly autonomous and directing towards developmental forms (including utopian images, "images of desired reality" [15, p.44]).

\section{Reciprocal genesis of an image; anthropological trajectory}

The image is created in a certain so-called genesis of the reciprocal ("reciprocal", genèse réciproque), which "oscillates between the impulsive act and the material and social environment, and vice versa" [15, p.38]. Durand views this relationship of reciprocity, mutual coupling, as a characteristic aspect of the anthropological perspective in which he also situates the problem of the image.

Imagery processes result from anthropological trajectory (traject anthropologique), which is the process of human development that occurs between the two dominants of the genesis. It is therefore a process of "constant exchange, which exists at the level of imagining between subjective and assimilative motives (impulses - pulsions. - I. B.) with objective calls emanating from the social and cosmic environment" [15, p. 38].

There is an overlap of the subjective psychological perspectives controlled by the connections of psychic states, the social and natural environment. All these perspectives cocreate the image, which for this reason may become privileged due to the multiplicity of information that it contains and carries. In addition, these perspectives can be included in various proportions; an image can thus become even a projection screen of the psyche 
with the hegemony of the intensity of the inner-mental state. The anthropological moment seems to be the most important for some researchers, because it manages the certain balance of the perspectives for the formation of images, their harmony and ordinary functioning. It indicates the role of the horizon of the possible adaptation of the species and its cultural development. Durand also identifies the basic dominants in the image structures such as postural (verticality-horizontality), alimentary and sexual, which he puts in reference to reflexology, developmental psychology and neurology, on biologicalanthropological and psychological grounds: "we assume as a hypothesis that there is a simple coexistence (concomitance. $-I$. B.) between body movements, neural centers and symbolic representations" [15, p. 51]. There is a combination of different levels of motor skills, neurobiological conditions and symbolic imaging.

Images are created in its isotopic classification based on the following structures: schizomorphic (heroic), synthetic (dramatic) and mystical (anti-phrase), in some sequential ordering. The epithet archetypes among others are active here: "bright — dark", "high low", "future - past", "hidden - cool, calm", substantial archetypes of "light - darkness", "air - miasma", "top - abyss", "heavens - hell", etc.

\section{Archetype as ante rem of an idea (moule affectivo-représentatif)}

In Durand's conception, archetypes are understood in a special way where particular attention is paid to their accumulation in humans and species' development. Archetypes are prototypes, but also "sediments" (engrams); they fulfill a kind of pre-rationality ordering experience in the space between anthropological structures of man and the environment of his life process. Thus, they are the basis for all forms of ordering, including thought and concepts - the archetype is a kind of ante rem of an idea.

Archetypes have a strong affective, emotional aspect which permeates the formation of representations on which the psychoanalysis, neo-psychoanalysis, and psychology of Jean Piaget often drew attention. There is always inseparability in the signifie and signifiant, symbol and image: "in the process of the symbol, the archetypal psychic movement and its imaginary counterpart, immersed in a given culture or cultural image at the given moment are inseparable" [15, p.263].

\section{Philosophical discovery of images}

The image penetrates into cognitive activities. It can be seen as an auxiliary factor in presenting ideas, concepts and relationships between them. Image is used as an intermediary agent in cognitive processes. Its strongest theoretical shots indicate its possible a priori position. In the first role ("auxiliary") it is usually appreciated and used by philosophy, e.g., a Platonic one. It serves to pave the way for the mind to the essential cognition. Here, it can function as an auxiliary metaphor, image and rhetorical language. Images can also be seen as intermediate forms, transient between mental structures of cognition and empirical data, allowing for the creation of a synthetic unity of sensations and to "behold in mental images", to consider various conceivable possibilities of phenomena and processes. In terms of the apriority of the image, it brings closer to "real" and "true", forming a "simple living unitywhole" (Bergson). The image itself can therefore be interpreted as a "guide of meaning" (le fils conducteur; Bachelard): "It is rather a human trace of belonging to the world, to life, to truth..." [1, p.180], expressing a human situation in the most authentic way. 


\section{Atlas of images}

The atlas of images should concern the relationship with the working principles of contradiction, exclusion, causality, analogues and similarity between them. All this provides the possibility of a real compendium, atlas, but also creates tools for understanding the meanings and determining a certain intensity of their reception and responding to them. Thus it is possible to create image atlases. They will affect many regions in which the image is active. There are many of forms of images - visual images have a hegemonic position, but beyond them we form their multiplicity. Images can be divided into material, mental, visual, linguistic, musical, sensory-motor, perceptual, memory, anticipative, unconscious, matrix ones [1], and many of them are further divided into a lot of their subtypes. The images can be seen as a configuration of the "tree of images" [16], even considering the objections to building this type of "tree structures" as hierarchic, too abruptly assigning importance to a high level of generality [17]. There is the presence of certain "families" or "swarms" of images related by meanings, ways of forming, formal features, but their impact cannot be hierarchically associated with some "greater" importance.

Images are diverse, they connect the poles of sensuality and abstract thinking and they have a supreme role in cognitive processes, creating a culture, a practical everyday life and they penetrate through the human world.

\section{Development of thinking about archetype and matrix images}

Thus, the concepts of archetype and archetypal image have undergone a long evolution, even if one considers only modern philosophy and philosophico-anthropological approaches, and if the perspective is expanded to develop the concept of the archetype in general, then these changes in terms, definitions and formulas are extensive. Thus, the archetype embraced the meanings of the basic ideas according to which the world was created: pure structural forms conditioning the development of reality, pure substantive forms operating in the mind and enabling the capture and understanding of empirical content. Jung himself knew these meanings well when he began to combine them with anthropological and evolutionary perspectives. They were embedded in the categories of collective imagination, preformations of the grip and understanding of social reality. They are also embedded in the processes of the evolution in the level of biological possibilities of human cognition and reference to the world in which they gained meaningful psychological forms of expression in instinct patterns of action. After superimposing these perspectives, they began to adhere to determined patterns or matrices of meaning, without losing the previous references at all. In Jung's approach, there was a connection between archetypes in the form of general matrices for the development of reality and mind, hence their great and philosophical significance in his conception.

The Bachelardian reference and approach to the notion of archetype was significantly modified; however, it did not have consequences for developmental forms of reality, but rather for certain matrices embedding and binding initially man to the existence of nature. Durand followed Bachelard's path of understanding. For him, the schemes of anthropological structures became the foundation of the process of "becoming man". He understood the archetype as an affective-representative node and core of ante rem for an idea. In terms of Wunenburger matrix images, the archetype is one of their forms and implies native informations on derivative images. Therefore, there remains a common ground in these shots - the 
archetype and matrix image bind the cumulative form of information collapsed into the general structure and the predominant associated with the biological and evolutionary basis. Archetype as a matrix image need not necessarily refer to such a substrate and can only mean a certain compression of information about the general structure affecting a series of its updated forms or specific images associated with the matrix of semantics.

Thus, in twentieth century views on the subject, the archetype and matrix image mean the following: 1 . In an evolutionary perspective - psychological expression of an instinctive pattern of behavior; 2 . In a socio-anthropological grasp - category of collective imagination; 3 . In a philosophical, hermeneutic perspective - pattern of meaning; 4. In a philosophico-anthropological contemporary grasp - a primeval image intermediary between outer reality and anthropological structures - an affective-representative node; ante rem of an idea; 5 . In a reflection in the philosophy of images - as "matrix image" - native information on derivative images. Contemporary research on the subject can be understand in two ways: the matrix image can be understood as rooted in the anthropological structures and neurobiological bases or it can be conceived as a structure of compact information about meanings important for life in a given culture.

\section{References}

1. Wunenburger, J.-J. (2011), The Philosophy of Images, transl. by Stróżyński, T., Gdańsk: Słowo-obraz/ terytora.

2. Jung, C.G. (1969), The Archetypes and the Collective Unconscious, in Jung, C.G., The Collected Works, vol. 9.1, Princeton, New Jersey: Princeton University Press.

3. Jung, C. G. (1969), On the Psychology of Trickster Figure, in Jung, C. G., The Collected Works, vol. 9.1, Princeton, New Jersey: Princeton University Press.

4. Brooke, R. (1991), Jung and Phenomenology, London, New York: Routledge.

5. Olejarczyk, A. (2018), Collective Memory and Common Imagination - Archetypes in the Perspective of the Theory of Sign, in Błocian, I. and Kuźmicki, A. (eds), Contemporary Influences of C. G. Jung's Thought, Leiden, Boston: Brill, pp. 96-115.

6. Paź, B. (2019), Transcendetalia or Transcendentalism. Available at: http://www.ptta.pl/km/index. php?id=symp_str_7 (accessed: 05.08.2019).

7. Błocian, I., The Archetype of the Trickster, in C. G. Jung's Writings, (in print).

8. Progoff, I. (1955), Jung's Psychology and its Social Meaning, New York: Grove Press.

9. Progoff, I. (1956), The Death and Rebirth of Psychology. An Integrate Evaluation of Freud, Adler, Jung and Rank and the Impact of Their Culminating Insight of Modern Man, New York: The Julian Press.

10. Samuels, A. (1993), The Political Psyche, London, New York: Routledge.

11. Francuz, P. (ed.) (2007), The Images in Mind. Studies on Perception and Imagination, Warszawa: The Wydawnictwo Naukowe Scholar.

12. Bachelard, G. (2004), La terre et les rêveries du repos, Paris: Corti.

13. Durand, G. (1992), Les structures anthropologiques de l'imaginaire. Introducton à l'archétypologie générale, ed. XI, Paris: Dunod.

14. Błocian, I., The Concept of an Archetype against the Background of Philosophical Approaches to the Unconscious, in Artamoshkina, L., Błocian, I. and Morawski, K., The Unconscious, Image and Politics, (in print).

15. Morawski, K. (2019), Imaginaries of the Political: Image and Hegemony, Wrocław: Wydawnictwo Uniwersytetu Wrocławskiego.

16. Wunenburger, J.-J. (2002), La vie des images, Grenoble: PUG.

17. Deleuze, G. and Guattari, F. (2015), Capitalism and Schizophrenia, vol. 2: Thousand plateau, transl. by Bednarek, J., Warszawa: Fundacja Nowej Kultury Bęc, Zmiana. (In Polish)

Author's information:

Ilona Błocian - Dr. Hab., Associate Professor; ilona.blocian@uwr.edu.pl 


\title{
Архетип и матричный образ (потенциальные формы образа)
}

\author{
И. Блочан \\ Вроцлавский университет, \\ Республика Польша, 50-137, Вроцлав, Университетская пл., 1
}

Для цитирования: Błocian I. Archetype and matrix image (Potential Forms of an Image) // Becтник Санкт-Петербургского университета. Философия и конфликтология. 2021. Т. 37. Вып. 1. C. 154-161. https://doi.org/10.21638/spbu17.2021.112

Статья посвящена анализу потенциальных форм образа в культуре и развитию юнгианского понятия архетипа у Ж.-Ж. Вуненбургера, Г. Башляра, Ж. Дюрана и в современных исследованиях культуры. В концепции К. Г. Юнга понятие «архетип» объединяло архетип в себе, ноумен и архетипический образ в культуре, понимаемый как феноменальное проявление архетипических форм в пространстве и времени, исторической и социальной реальности. Это различие восходит к идеям Канта, что вполне осознавалось Юнгом, характеризовавшим кантовскую мысль в своих произведениях как «школу философской критики». Время от времени в исследованиях концепции Юнга анализируется его подход к трансцендентализму (3. Розинска) и используется определенный тип его специфически эволюционной интерпретации. Архетип, будучи «вещью в себе», определяет появление феноменальных форм в пространстве и времени, историческом и социальном мире, оставаясь при этом вне прямой связи с ними и апеллируя к эволюционно активной сфере бессознательного как антропологической данности. В то время как архетипический образ выражает постоянное приближение коллективного воображения к выражению смыслового ядра архетипа в себе. В современных представлениях понятие архетипа существенно трансформировалось. Из психического выражения эволюционного паттерна он превратился в изначальный образ - аффективно-репрезентативный узел, опосредующий антропологические структуры и внешнюю реальность; из герменевтического паттерна - в матричный образ - исходную информацию о производных образах. В статье продемонстрированы возможности трактовки архетипа как в связи с антропологическими структурами, так и в качестве культурного образа.

Ключевые слова: архетип, матричный образ, изначальный образ, антропологические структуры, архетипы-эпитеты, субстанциальные архетипы, Юнг, Башляр, Дюран, Вуненбургер.

Статья поступила в редакцию 27 января 2020 г.; рекомендована в печать 29 декабря 2020 г.

Контактная информация:

Блочан Илона - д-р филос. наук, доц.; ilona.blocian@uwr.edu.pl 